\title{
Fabrication and Output Evaluation of Si-Ge Multilayered Thermoelectric Element
}

\author{
Masatoshi OTAKE, Kenji SATO, Osamu SUGIYAMA* and Shoji KANEKO** \\ Hamamatsu Industrial Research Institute, 1-3-3, Shinmiyakoda, Hamamatsu-shi, Shizuoka 431-2103 \\ ${ }^{*}$ Fuji Industrial Research Institute, 2590-1, Obuchi, Fuji-shi, Shizuoka 417-8550 \\ **Department of Materials Science and Technology, Faculty of Engineering, Shizuoka University, \\ 3-5-1, Johoku, Hamamatsu-shi, Shizuoka 432-8561
}

\author{
p-n 多層型 Si-Ge 熱電素子の作製及び出力評価 \\ 大竹正寿·佐藤憲治 $\cdot$ 杉山 治* · 金子正治** \\ 静岡県浜松工業技術センター，431-2103 静岡県浜松市新都田 1-3-3 \\ *静岡県富士工業技術センター，417-8550 静岡県富士市大㴊 2590-1 \\ **静岡大学工学部物質工学科, 432-8561 静岡県浜松市城北 3-5-1
}

\begin{abstract}
$\mathrm{A} \mathrm{Si}_{0.8} \mathrm{Ge}_{0.2}$ multilayered thermoelectric element with ten pairs of $\mathrm{p}$-n layers was fabricated by simultaneous sintering and joining of $\mathrm{Si}-\mathrm{Ge}$ powders with a sandwiched alumina cloth. Every $\mathrm{p}-\mathrm{n}$ joint of the element was firmly connected without any cracks and the alumina layer inserted here remained unchanged even after a pulse-current sintering process. The maximum output, $P_{\max }$, of this element was determined in the temperature range of 473-1273 K, and then increased in proportion to the second order of the temperature difference between the hot and cold ends of the element. As a result, $P_{\max }$ was $120 \mathrm{~mW}$ when the temperature difference was $500 \mathrm{~K}$.
\end{abstract}

[Received April 14, 2004; Accepted June 24, 2004]

Key-words : Silicon-germanium, Gas atomization, Pulse-current sintering, Thermoelectric element, Multilayer

\section{Introduction}

For the reduction in energy consumption and the realization of a sustainable global environment, research works on thermal-electrical energy conversion have increased resulting in the development of effective thermoelectric materials. ${ }^{1), 2)}$ The thermoelectric element relevant to this work is usually fabricated by bridging each end of $\mathrm{p}$ - and n-type semiconductors with a metal plate, which generates electrical power by making use of the temperature difference between both ends of this bridged element. ${ }^{3,4)}$ Silicon-germanium $(\mathrm{Si}-\mathrm{Ge})$ is one of the thermoelectric materials used in a relatively high temperature range of $500-1000^{\circ} \mathrm{C} .^{5)} \mathrm{We}$ reported the thermoelectric properties of $\mathrm{p}$ - and n-type $\mathrm{Si}-\mathrm{Ge}$ dense bodies fabricated by pulse-current sintering (PCS) of Si-Ge gas-atomized powders ${ }^{6}{ }^{6}$ where both figures of merit increased monotonically with temperature up to $1073 \mathrm{~K}$ and became 0.56 and 0.66 , respectively, at this temperature. A thermoelectric element was also obtained by joining both types of semiconductor directly without a metal plate, where a slit was inserted between them except at the high-temperature part. ${ }^{7)}$ Thermoelectric elements using $\mathrm{Si}-\mathrm{Ge},{ }^{8)} \mathrm{Li}_{0.025} \mathrm{Ni}_{0.975} \mathrm{O}-\mathrm{Bi}_{0.4} \mathrm{Sr}_{0.6} \mathrm{PbO}_{3},{ }^{9)}$ and $\beta-\mathrm{FeSi}_{2}{ }^{10)}$ for the high-temperature application were fabricated by this process.

A p-n-joined $\mathrm{Si}_{0.8} \mathrm{Ge}_{0.2}$ thermoelectric element with a sandwiched alumina layer for strengthening was fabricated by simultaneous sintering and joining of $\mathrm{Si}-\mathrm{Ge}$ gas-atomized powders and an alumina cloth, however, its output was shown to be insufficient. ${ }^{11)}$ Thus, many elements should be connected electrically to increase the output for practical power supply. Multilayering of a p-n-joined element would be preferable for the enhancement of the output without the lowering of its strength. In this study, a multilayered element was fabricated by stacking $\mathrm{p}$ - and n-type semiconductors alternately for simplification of the process, as illustrated in Fig. 1, followed by the evaluation of its output.

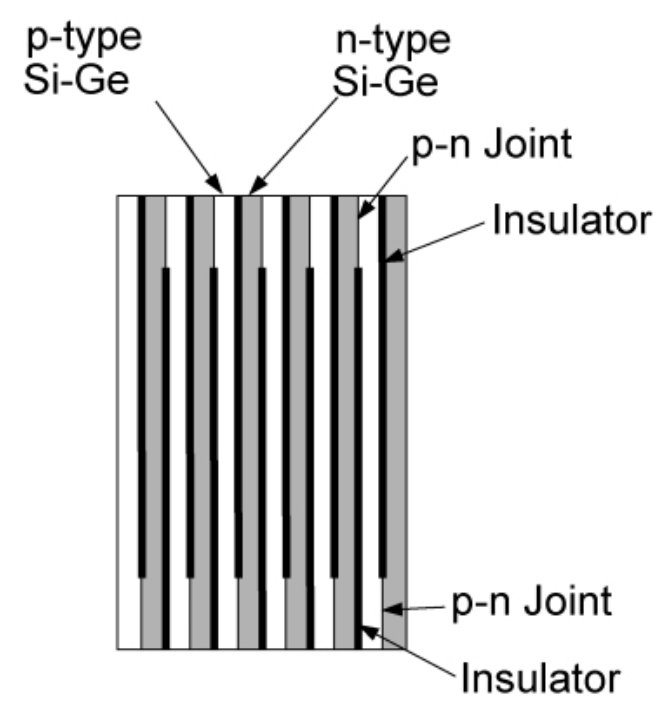

Fig. 1. Multilayered element.

\section{Experimental}

2.1 Fabrication of multilayered element

Both p- and n-type $\mathrm{Si}-\mathrm{Ge}$ powders were prepared by a gas atomization technique, as described in a previous paper. ${ }^{12)}$ The chemical composition of the p-type powder obtained was Si $79.7 \mathrm{~mol} \%$, Ge $20.1 \mathrm{~mol} \%$, and B $0.20 \mathrm{~mol} \%$; that of the n-type powder was Si $79.8 \mathrm{~mol} \%$, Ge $20.0 \mathrm{~mol} \%$, and P 0.20 $\operatorname{mol} \%$.

An alumina cloth of $30 \mathrm{~mm}$ diameter and $2 \mathrm{~mm}$ thickness (NICHIAS No.5475, Japan) as an insulator was sandwiched between the $\mathrm{p}$ - and n-type $\mathrm{Si}-\mathrm{Ge}$ powders of $1 \mathrm{~g}$ each, which were charged ten times in a cylindrical carbon vessel with an inner diameter of $30 \mathrm{~mm}$. Then it was uniaxially compressed 
with a carbon punch at $49 \mathrm{MPa}$. The alumina cloth was cut off partly for the direct contact between the p- and n-type Si-Ge powders in advance. Simultaneous sintering and joining were carried out by heating at $1523 \mathrm{~K}$ for a soaking time of $180 \mathrm{~s}$ in vacuo using a PCS apparatus (Sumitomo Coal Mining SPS-1030). The as-sintered body of $30 \mathrm{~mm}$ diameter and 15 $\mathrm{mm}$ thickness was further processed into a rectangle using a cutting machine. Nickel plates were welded on p- and n-type surfaces of both ends of the multilayered element with silver solder prior to the output measurement.

\subsection{Measurement of output}

The output of a sample was determined using a measurement system equipped with a heating controller and electrical measurement devices. ${ }^{11)}$ The hot end of the sample was heated at the prescribed temperatures ranging from 473 to $1273 \mathrm{~K}$. Voltage and electric current generated from the sample were measured using data logger at each temperature. After a starting signal was sent from a trigger generator, voltage $(V)$ and temperatures at both hot and cold ends $\left(T_{\mathrm{h}}\right.$ and $\left.T_{\mathrm{c}}\right)$ were monitored using the data logger while the current $(I)$ was controlled from 0 to $1.0 \mathrm{~A}$ in $5 \mathrm{~s}$ by an electronic device for changing an external resistance.

\section{Results and discussion}

Figure 2 shows the appearance of the multilayered element with 10 pairs of p- and n-type Si-Ge semiconductors $15 \mathrm{~mm} \times$ $25 \mathrm{~mm} \times 14 \mathrm{~mm}$ and weighing $14.7 \mathrm{~g}$. These $\mathrm{p}-\mathrm{n}$ joints were firmly connected to each other without any cracks. The alumina layers became thinner and blackish via the PCS process. Both thicknesses of $\mathrm{Si}-\mathrm{Ge}$ and alumina layers were approximately 600 and $80 \mu \mathrm{m}$, respectively. The alumina layers existed without a significant reaction with the $\mathrm{Si}-\mathrm{Ge}$ layers even after the sintering process, which may be attributed to the short sintering time of $300 \mathrm{~s}$ of the PCS process.

Figure 3 shows that both high open voltage and shortcircuit current were obtained at a high heating temperature due to a large temperature difference. The slope of the straight line indicates the internal resistance including the contact resistance between the element and the conductor. This slope gradually decreased as the heating temperature increased, presumably resulting from the lowering of the contact resistance at relatively high temperatures. The internal resistance of this element was $1.95 \Omega$ on average in the temperature range of $478-1277 \mathrm{~K}$. Furthermore, the maximum output $\left(P_{\max }\right)$, which was the maximum value of the product of voltage and electric current, was calculated at each heating temperature

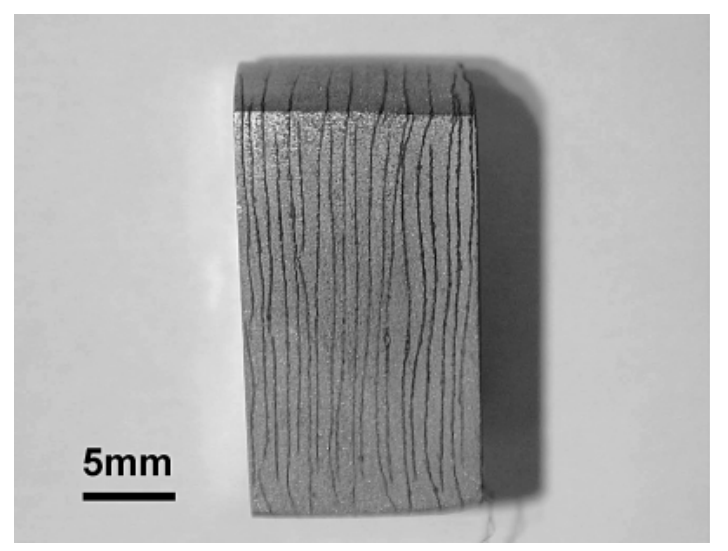

Fig. 2. Multilayered element with alumina layers. for the evaluation of the element. The maximum output was compared with that of the $\mathrm{p}-\mathrm{n}$-joined $\mathrm{Si}-\mathrm{Ge}$ thermoelectric element with a sandwiched alumina layer (joined element) reported in a previous paper, ${ }^{11)}$ as shown in Fig. 4. Here, the $P_{\max }$ of the element was proportional to the second order of the temperature difference, as expected from the theoretical consideration. ${ }^{13)}$ The difference in $P_{\max }$ between these two elements increased as the temperature difference increased, indicating the effectiveness of the integration here for the enhancement of the output. The $P_{\max }$ of the multilayered element was $120 \mathrm{~mW}$, which was approximately 3.5 times higher than that of the joined element when the temperature difference was $500 \mathrm{~K}$.

The internal resistance $r$, temperature difference $\Delta T$, and the output at $1273 \mathrm{~K}$ of the joined and multilayered elements are summarized in Table 1. The small $\Delta T$ of the multilayered element occurred due to its large cross-sectional area caused by the integration, which may be improved by the use of cooling water or heat-radiation fins. This integration technique

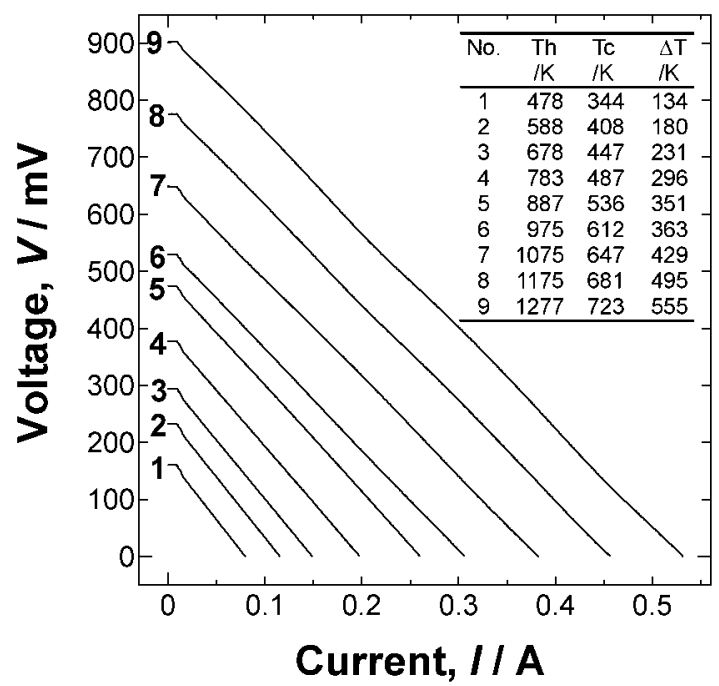

Fig. 3. Relationship between output voltage and electric current of multilayered element with nine heating temperatures.

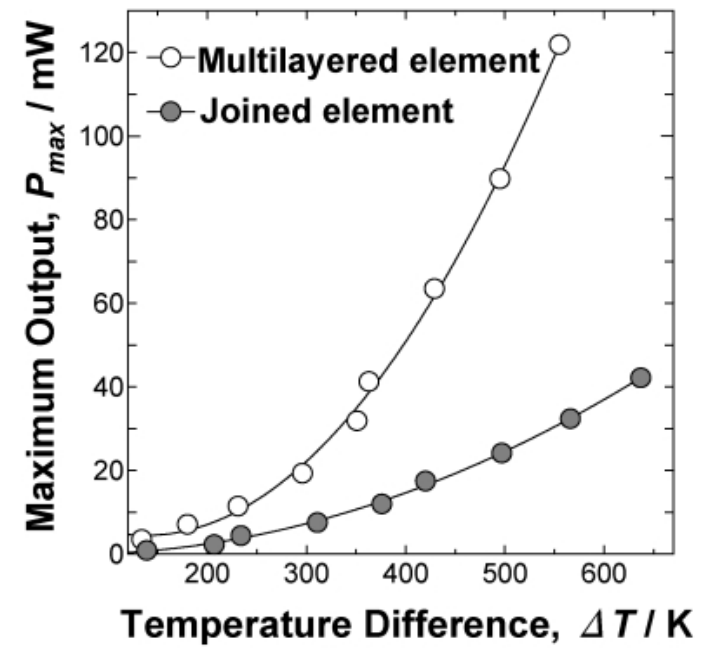

Fig. 4. Maximum outputs, $P_{\max }$, of multilayered and joined elements. 
Table 1. Comparison of Joined and Multilayered Elements (Heated at $1273 \mathrm{~K}$

\begin{tabular}{lcccc}
\hline & $\begin{array}{c}\text { Internal } \\
\text { Resistance }\end{array}$ & $\begin{array}{c}\text { Temperature } \\
\text { Difference }\end{array}$ & \multicolumn{2}{c}{ Output } \\
& $r / \Omega$ & $\Delta T / \mathrm{K}$ & $\mathrm{P} / \mathrm{mW}$ & $\mathrm{P} / \mathrm{mW}$ \\
\hline Joined element & 0.9 & 647 & 48 & 48 \\
Multilayered element & 1.7 & 495 & 120 & 12 \\
\hline
\end{tabular}

would be applicable for the fabrication of the thermoelectric power generator because of many advantages such as supply of higher voltage, simplification of assemblies, and reduction in weight.

\section{Conclusion}

A Si-Ge multilayered thermoelectric element with 10 pairs of joined $\mathrm{p}$ - and n-type Si-Ge layers was fabricated by pulsecurrent sintering of $\mathrm{p}$ - and n-type gas-atomized powders. The maximum output of the element was $120 \mathrm{~mW}$ when the temperature difference between the hot and cold ends of the element was $500 \mathrm{~K}$. The integration of the elements here was effective for the miniaturization and process simplification as well as the output enhancement.

\section{References}

1) Rowe, D. M., "CRC Handbook of Thermoelectrics," Ed. by Rowe, D. M., CRC Press, London, U. K. (1995) pp. 1-5.

2) Rowe, D. M., J. Power Sources, Vol. 19, pp. 247-259 (1987).

3) Wood, C., Rep. Prog. Phys., Vol. 51, pp. 459-539 (1988).

4) Kibayashi, Y., "Thermoelectrics, Principals and Applications," Ed. by Sakata, R., Realize, Tokyo (2001) pp. 329-348 [in Japanese].

5) Vining, C. and Fleurial, J. P., "Silicon Germanium, An Overview of Recent Developments," Ed. by Rowe, D. M., Babrow Press, Cardiff, U. K. (1991) pp. 1-14.

6) Otake, M., Sato, K., Sugiyama, O. and Kaneko, S., J. Ceram. Soc. Japan, Vol. 111, pp. 907-911 (2003).

7) Stohrer, U., Voggesverger, R. Wagner, G. and Birkholz, U., Proc. 8th Int. Conf. Thermoelectric Energy Conversion, pp. 130-132 (1989).

8) Noguchi, T., Proc. 16th Int. Conf. Thermoelectrics, pp. 207-214 (1997).

9) Shin, W., Murayama, N., Ikeda, K. and Sago, S., Jpn. J. Appl. Phys., Vol. 39, pp. 1254-1255 (2000).

10) Gross, E., Powalla, M., Stohrer, U. and Birkholz, U., Proc. 9th Int. Conf. Thermoelectrics, pp. 336-342 (1990).

11) Otake, M., Sato, K., Sugiyama, O. and Kaneko, S., J. Electrochem. Soc., in submission.

12) Otake, M., Sato, K., Sugiyama, O. and Kaneko, S., J. Ceram. Soc. Japan., Vol. 111, pp. 749-754 (2003).

13) Goldsmid, H. G.., "CRC Handbook of Thermoelectrics," Ed. by Rowe, D. M., CRC Press. London, U. K. (1995) pp. 19-25. 